\title{
Short communication: Massive erosion in monsoonal central India linked to late Holocene land cover degradation
}

\author{
Liviu Giosan $^{1}$, Camilo Ponton ${ }^{1,2, a}$, Muhammed Usman ${ }^{3}$, Jerzy Blusztajn ${ }^{1}$, Dorian Q. Fuller ${ }^{4}$, \\ Valier Galy ${ }^{5}$, Negar Haghipour ${ }^{3}$, Joel E. Johnson ${ }^{6}$, Cameron McIntyre ${ }^{3,7, b}$, Lukas Wacker ${ }^{7}$, and \\ Timothy I. Eglinton ${ }^{3,5}$ \\ ${ }^{1}$ Geology \& Geophysics, Woods Hole Oceanographic Institution, Woods Hole, MA 02543, USA \\ ${ }^{2}$ MIT/WHOI Joint Program in Oceanography/Applied Ocean Science and Engineering, \\ Cambridge, MA, USA \\ ${ }^{3}$ Geological Institute, ETH Zurich, 8092 Zurich, Switzerland \\ ${ }^{4}$ Institute of Archaeology, University College London, London, UK \\ ${ }^{5}$ Marine Chemistry \& Geochemistry, Woods Hole Oceanographic Institution, Woods Hole, MA 02543, USA \\ ${ }^{6}$ Earth Sciences, University of New Hampshire, Durham, NH, USA \\ ${ }^{7}$ Laboratory of Ion Beam Physics, ETH Zurich, 8093 Zurich, Switzerland \\ anow at: Division of Geological and Planetary Sciences, California Institute of Technology, \\ 1200 E. California Blvd., Pasadena, CA 91125, USA \\ bnow at: Scottish Universities Environmental Research Center, E. Kilbride, G75 0QF, UK
}

Correspondence to: Liviu Giosan (lgiosan@whoi.edu)

Received: 26 May 2017 - Discussion started: 20 June 2017

Revised: 23 October 2017 - Accepted: 30 October 2017 - Published: 1 December 2017

\begin{abstract}
Soil erosion plays a crucial role in transferring sediment and carbon from land to sea, yet little is known about the rhythm and rates of soil erosion prior to the most recent few centuries. Here we reconstruct a Holocene erosional history from central India, as integrated by the Godavari River in a sediment core from the Bay of Bengal. We quantify terrigenous fluxes, fingerprint sources for the lithogenic fraction and assess the age of the exported terrigenous carbon. Taken together, our data show that the monsoon decline in the late Holocene significantly increased soil erosion and the age of exported organic carbon. This acceleration of natural erosion was later exacerbated by the Neolithic adoption and Iron Age extensification of agriculture on the Deccan Plateau. Despite a constantly elevated sea level since the middle Holocene, this erosion acceleration led to a rapid growth of the continental margin. We conclude that in monsoon conditions aridity boosts rather than suppresses sediment and carbon export, acting as a monsoon erosional pump modulated by land cover conditions.
\end{abstract}

\section{Soil erosion in the Holocene}

On decadal to millennial timescales, climate is the principal natural control on soil erosion via changes in temperature and precipitation as well as their impact on vegetation type and cover (Allen and Breshears, 1998; Reichstein et al., 2013). Global sediment budgets for the Holocene indicate that humans surpassed these natural controls and became the main driver of soil erosion by at least 2000 years ago (Mont- gomery, 2007; Wilkinson and McElroy, 2007; Dotterweich, 2013). Transfer of sediment, carbon and solutes from land to ocean is of crucial importance for understanding continental margin architecture as well as carbon and other elemental cycles. For example, soils contain about 2 times more carbon than the atmosphere and, as a result, small changes in the residence time of organic carbon in soils can significantly affect the atmospheric inventory of carbon dioxide (Lal, 2004). Besides heterotrophic microbial respiration, erosion is the 
principal process that releases carbon from soils. Eroded carbon can subsequently be degraded/reburied along the aquatic continuum to the ocean (Stallard, 1998; Aufdenkampe et al., 2011; van Oost et al., 2012).

In the absence of historical documentation of human impacts, the complexity of soil erosion hampers the reconstruction of carbon transfer processes prior to the last few centuries (e.g., Hoffmann et al., 2013; Dotterweich, 2013; Vanwalleghem et al., 2017). Consequently, global carbon budgets implicitly assume steady state conditions for lateral transport and carbon degradation along the aquatic continuum in pre-industrial times (Battin et al., 2009; Regnier et al., 2013; Chappell et al., 2016). In contrast, abundant archaeological and geological evidence (e.g., van Andel et al., 1990; Bork and Lang, 2003; Bayon et al., 2012; Dotterweich, 2013) as well as modeling (Kaplan et al., 2010; Wang et al., 2017) suggests widespread impacts of early human land use on continental landscapes, soil erosion and associated carbon transfer processes.

Here we present a soil erosion history from the Indian Peninsula recorded in a sediment core retrieved near the mouth of the Godavari River (Fig. 1) in the Bay of Bengal (NGHP-01-16A at $16^{\circ} 35.6^{\prime} \mathrm{N}, 82^{\circ} 41.0^{\prime} \mathrm{E} ; 1268 \mathrm{~m}$ water depth; Collett et al., 2015). The age model for the core based on 11 radiocarbon dates on mixed planktonic foraminifera was previously published by Ponton et al. (2012). The Godavari Basin was not affected by tectonics on the Holocene timescale or by glacial/snow meltwater and strong orographic precipitation, which augment and complicate the water and sediment discharge of the larger Himalayan rivers like the Ganges or Brahmaputra. Instead, it integrates rainfall from the Core Monsoon Zone (CMZ), the region of central India that is representative of both the mean monsoon regime and its fluctuations over the peninsula (see Ponton et al., 2012, and references therein). Consequently, over $90 \%$ of the Godavari's water discharge into the Bay of Bengal derives from summer monsoon precipitation (Rao et al., 2005), making its sedimentary deposits a prime target for continental climate reconstructions and a repository for sedimentary proxies of erosion prior and after the Neolithic adoption of agriculture in central India.

\section{The Godavari sediment system}

Originating at an elevation of $920 \mathrm{~m}$ in the Sahyadri coastal range (aka Western Ghats) near the Arabian Sea coast, the Godavari crosses the entire Indian Peninsula toward the Bay of Bengal (Fig. 1a). Currently the water discharge of the river is $\sim 85 \mathrm{~km}^{3} \mathrm{yr}^{-1}$ with a sediment load of $\sim 175 \mathrm{Mt} \mathrm{yr}^{-1}$ (Syvitski and Saito, 2007). Because the coastal range limits penetration of the Arabian Sea moisture delivered by the monsoon, precipitation in the Godavari Basin primarily originates from the Bay of Bengal (Gunnell et al., 2007). As a result, the climate is most humid at the coast (i.e., Eastern
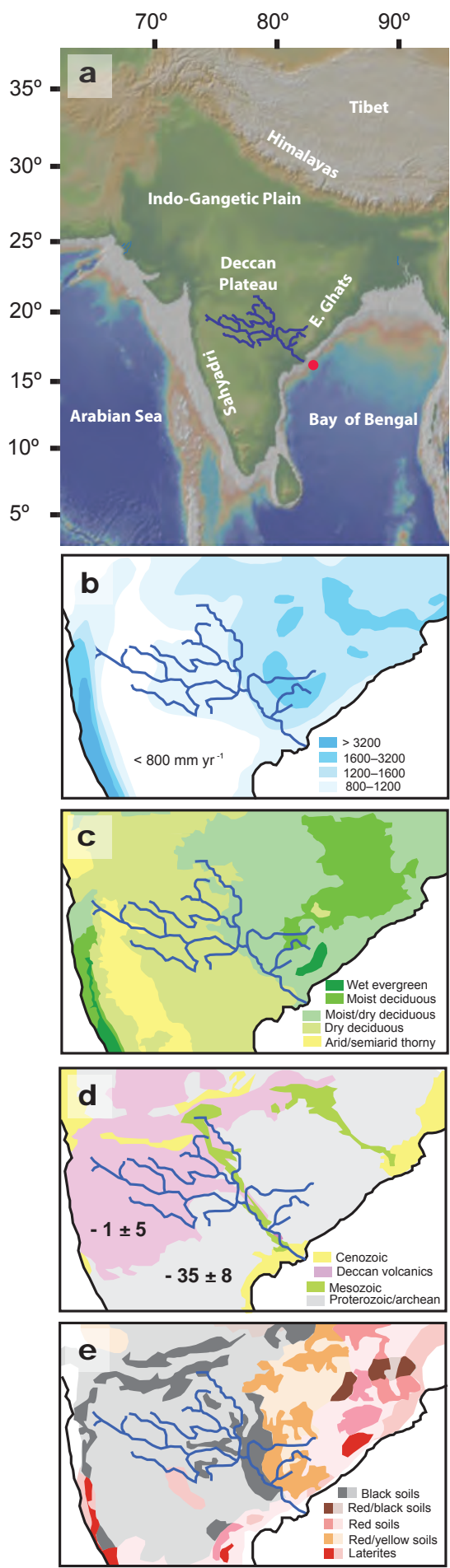

Figure 1. Godavari River drainage basin in its (a) physiographical, (b) hydroclimatic (Asouti and Fuller, 2008), (c) ecological (Asouti and Fuller, 2008), (d) geological (Bikshamaiah and Subramanian, 1988) and (e) soil cover (NBSS \& LUP, 1983) context. Core NGHP01-16A location is indicated in (a) by the red dot. Average bedrock $\varepsilon \mathrm{Nd}$ values are shown in (d). 
Ghats range) and becomes increasingly arid toward the interior on the Deccan Plateau (Fig. 1b). The natural vegetation reflects this gradual decrease in moisture: the headwaters on the Deccan Plateau are dominated by $\mathrm{C}_{4}$-plant thornbush savannah adapted to dry conditions, whereas $\mathrm{C}_{3}$ flora (deciduous forests) are dominant in the Eastern Ghats (Asouti and Fuller, 2008; Fig. 1c).

Sediments transported by the Godavari are sourced from two major geological units (Bikshamaiah and Subramanian, 1988). The upper river basin developed on the Deccan Traps, a large igneous province consisting of relatively young flood basalts (Cretaceous to early Neogene) that largely span the Deccan Plateau. The lower river basin developed over old Proterozoic to Archaean crystalline igneous/metamorphic rocks of the Indian Craton (Fig. 1d). The relatively young Deccan basalts retain a highly radiogenic mantle-derived $\mathrm{Nd}$ isotope composition ( $\varepsilon \mathrm{Nd}$ of $+1 \pm 5)$, while the old continental crust of the Indian Craton has a relatively unradiogenic isotopic composition ( $\varepsilon \mathrm{Nd}$ of $-35 \pm 8$ ), yielding a sharp contrast between geological end-members. Thus, the sediment provenance for the Godavari sediments can be deduced from the $\mathrm{Nd}$ isotopic signatures of the detrital inorganic fraction in our core because the Nd signal remains unmodified through bedrock weathering processes (McLennan and Hemming, 1992; DePaolo, 1988).

Black soils cover the Deccan Plateau, whereas red soils are generally typical for the Eastern Ghats (Bhattacharyya et al., 2003; Fig. 1d). Although both types of soils have been affected by land use since prehistorical times, the black soils of the arid to semiarid Deccan Plateau appear to be the most degraded at present (Singh et al., 1992). Intense erosion within the basin is reflected by the inordinately large sediment load of the Godavari (Bikshamaiah and Subramanian, 1988) similar to other monsoonal rivers (Summerfield and Hulton, 1994). In contrast to the dynamic Himalayan rivers of the Indo-Gangetic alluvial plain, the Godavari and its tributaries are incised in rock or alluvium and have relatively stable sandy channels. As for other rivers affected by storms (Edwards and Owens, 1991; Hilton et al., 2008), extreme rainfall events are disproportionately important for erosion in the Godavari watershed and in subsequent transport of sediments to the ocean (Kale, 2003). Given their incised morphology, shifts in channel position in response to floods are, however, rare above the Godavari Delta (Kale, 2002). Floodplains are limited in extent ( $2 \%$ of the basin; Bikshamaiah and Subramanian, 1988), and loss of sediments to overbank deposition is minor (Kale, 2002). Therefore storage is minimal in these intermediate alluvial reservoirs that normally would increase the residence time of sediments, including particulate organic carbon.

Once reaching the Bay of Bengal, sediment delivered by the Godavari has constructed a large Holocene delta (Rao et al., 2005; Cui et al., 2017). Offshore from the Godavari mouth, a persistent sediment plume extends over $300 \mathrm{~km}$ during the monsoon season, when over $90 \%$ of the fluvial sed- iment is discharged (Sridhar et al., 2008). Because the shelf in front of the delta is unusually narrow (i.e., under $10 \mathrm{~km}$ at our core location) copious sediment deposition takes place directly on the continental slope, resulting in sediment accumulation rates as high as $250 \mathrm{~cm} \mathrm{kyr}^{-1}$ (Ponton et al., 2012). Owing to the narrow shelf, changes in sea level would also have minimal effects on sediment deposition at our site, especially after the early Holocene when the global sea level reached within a few meters of modern values (Lambeck et al., 2014). For these reasons our core located close to the river mouth $(\sim 35 \mathrm{~km})$ is unlikely to contain any significant contributions from other sediment sources, in agreement with previous studies (e.g., Bejugam and Nayak, 2017).

The relatively simple sedimentary regime of the Godavari system in combination with the monsoon-dominated climatology and simple geology of the Godavari Basin allows for relatively straightforward interpretation of sediment sources and transfer processes. The monsoon wash load is rapidly and directly delivered to the continental margin without significant trapping in intermediate depocenters along the river. As the suspended load makes up over $95 \%$ of the total sediment transported by the Godavari (Syvitski and Saito, 2007), the wash-load-derived terrestrial proxies are representative of the production of fine-grained sediment in the basin. Potential contributions from resuspension of shelf sediments cannot be excluded but are likely minor due to the narrowness of the shelf; furthermore, given the large sedimentation rates on the shelf itself (Forsberg et al., 2007), the resuspended sediment is expected to be quasi-contemporaneous with sediments arriving on the slope directly from the river plume.

\section{Hydroclimate in the Core Monsoon Zone}

We have previously reconstructed the Holocene paleoclimate using the same sediment core discussed herein (Ponton et al., 2012; Zorzi et al., 2015). Terrestrial reconstructions were based on the carbon isotopic compositions of higher plant leaf-wax biomarkers (i.e., long-chain $n$-alkanoic acids $\mathrm{C}_{26-32}$ ) and pollen, whereas contemporaneous sea surface paleoceanographic conditions in front of the Godavari Delta came from the oxygen isotopic composition of planktonic foraminifer Globigerinoides ruber. Sedimentary leaf waxes provide an integrated $\delta^{13} \mathrm{C}$ record of the flora in the $\mathrm{CMZ}$ that document an increase in aridity-adapted vegetation $\left(\mathrm{C}_{4}\right.$ plants) after the monsoon maximum in the early Holocene (Ponton et al., 2012; Fig. 2). The overall trend of the $\delta^{13} \mathrm{C}$ leaf-wax record agrees with the view that the seasonality of Northern Hemisphere insolation (Ponton et al., 2012) led to progressively weaker monsoons over the Holocene. However, two clear aridification steps are evident: between $\sim 5000$ and 4500 years ago, and $\sim 1700$ years ago (Fig. 2). Pollen from the same core (Zorzi et al., 2015) reinforces these conclusions: coastal forest and mangrove pollen (Fig. 2) that are typical for the more humid coastal regions 

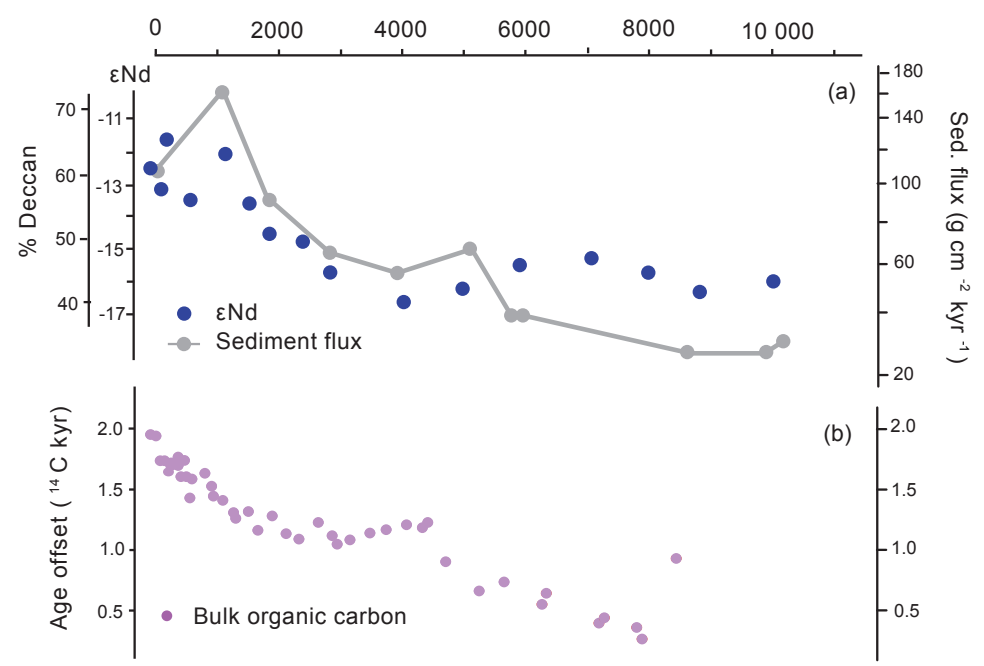

(b)
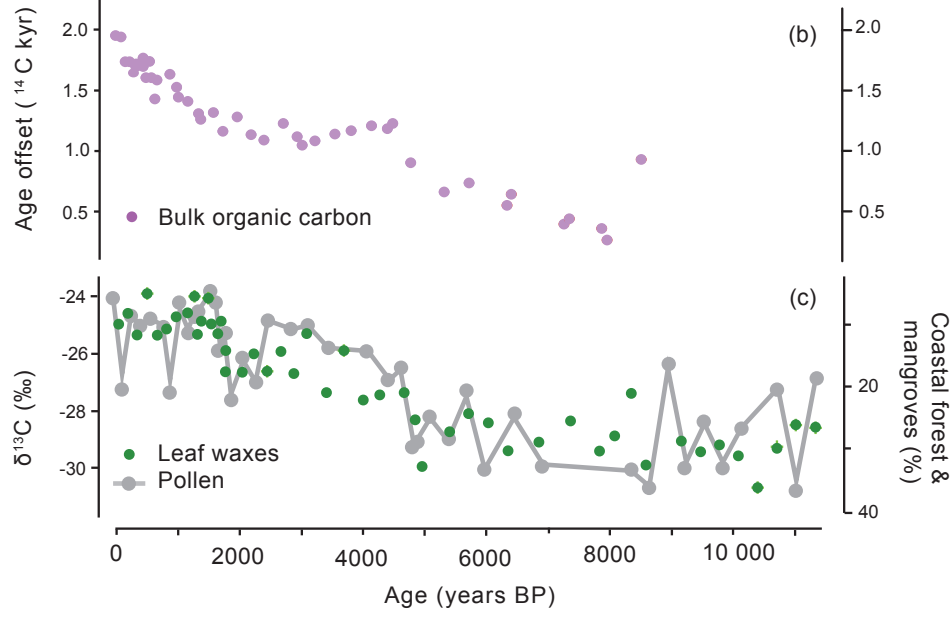

Figure 2. Paleoenvironmental reconstructions from core NGHP-01-16A for the Core Monsoon Zone as integrated by the Godavari River: (a) sediment fluxes as mass accumulation rates and sediment sources from Nd isotope fingerprinting (Deccan Trap sediment contribution is estimated from a two-end-member model; see text and Supplement); (b) TOC radiocarbon age offset relative to depositional age; (c) hydroclimate and ecology from pollen (Zorzi et al., 2015) and leaf-wax carbon isotopes (Ponton et al., 2012).

of the Eastern Ghats and Godavari Delta declined over the Holocene.

Dryness-adapted thornbush pollen from the Deccan Plateau increased substantially after the second aridification step $\sim 1700$ years ago, overlapping well with the maximum contribution of $\mathrm{C}_{4}$ plant-derived leaf waxes (see Zorzi et al., 2015). For the same time interval, the ice-volume-corrected oxygen isotopic composition of planktonic foraminifer Globigerinoides ruber documented a series of low values interpreted as high-salinity events at the Godavari mouths (see Ponton et al., 2012). Together these continental and oceanic records suggest that the $\mathrm{CMZ}$ aridification intensified in the latest Holocene via a series of short drier episodes (Ponton et al., 2012). This interpretation is reinforced by speleothemderived records from central and northern India for the past thousand years (Sinha et al., 2011), and the overall evolution of the CMZ hydroclimate as seen from our core is supported by local reconstructions from the Lonar crater lake in central India (Prasad et al., 2014; Sarkar et al., 2015), Godavari Delta (Cui et al., 2017) and other records from the larger Indian monsoon domain (Gupta et al., 2003; Fleitmann et al., 2003; Prasad and Enzel, 2006; Berkelhammer et al., 2012; Dixit et al., 2014).

\section{Erosion in the Godavari Basin}

The Holocene sediment flux at our core location (Fig. 2) is representative of the Godavari continental slope (Mazumdar et al., 2009; Ramprasad et al., 2011; Joshi et al., 2014) and is driven by changes in the siliciclastic sedimentation rate as dilution by biogenic carbonates is less than $5 \%$ (Johnson et al., 2014). Despite a lower sea level at the time, the flux was relatively small in the early Holocene $\left(\sim 25 \mathrm{~g} \mathrm{~cm}^{-2} \mathrm{kyr}^{-1}\right)$ but began to increase after 6000 years ago $\left(\sim 40 \mathrm{~g} \mathrm{~cm}^{-2} \mathrm{kyr}^{-1}\right)$, as soon as the monsoon started to decline but well before the adoption of Neolithic agriculture and settlement of the savannah zone of the central peninsula ( $\sim 4500$ years ago; Fuller, 2011). Between 4000 and 3500 years ago permanent agricultural settlements spread throughout the Deccan Plateau. The associated small-scale metallurgy (copper working) requiring firewood together with the agricultural intensification probably also affected erosion via widespread deployment of two cropping seasons (Kajale, 1988; Fuller and Madella, 2001). As the climate remained arid, sediment fluxes stayed high despite a phase of agricultural abandonment and depopulation between $\sim 3200$ and 2900 years ago (Dhavalikar, 1984; Roberts et al., 2016). 
A further step increase in the sediment flux ( $\sim 90 \mathrm{~g} \mathrm{~cm}^{-2} \mathrm{kyr}^{-1}$ on average) occurred after $\sim 3000$ years ago, this time with no apparent concurrent change in climate. The Nd isotopic signal points to an increase in the Deccan sedimentary output at the time, after a muted variability earlier in the Holocene when the Indian Craton consistently provided $\sim 50-60 \%$ of the sediments (Fig. 2; see Supplement). Ferrimagnetic minerals interpreted as originating from the Deccan Plateau (Sangode et al., 2001; Kulkarni et al., 2014) also increase in late Holocene sediments in the Godavari Delta (Cui et al., 2017) and Bay of Bengal (Kulkarni et al., 2015), supporting our interpretation. Augmented Deccan input was suggested for the Godavari Delta even earlier after $\sim 6000$ years ago (Cui et al., 2017), in step with the initial aridification.

New improvements in agricultural technology became widespread in the Deccan Plateau, including use of iron agricultural tools (Mohanty and Selvakumar, 2001) that required firewood-fueled smelting (Fuller, 2008). A new phase of agricultural settlement began in the middle Godavari Basin (eastern Maharashtra) between $\sim 3000$ and $\sim 2800$ years ago (Brubaker, 2000). However, the largest boost in sediment flux occurred after $\sim 2000$ years ago, when the monsoon reached its driest phase and when further increases in population occurred, resulting in the founding of towns and the first cities of the region at the beginning of the Indian Historic Period (Allchin, 1995; Parabrahma Sastry, 2003). This doubling in sediment flux relative to the early Holocene values involved a basin-wide increase in erosion. The contribution from the Deccan Plateau, although at its maximum according to the $\mathrm{Nd}$ isotope mixing model, only accounts for a $15 \%$ shift in sediment source (Fig. 2).

Overall, watersheds with high precipitation have higher discharge, and discharge magnitude is considered a primary regulator for sediment and carbon erosional fluxes to the ocean (e.g., Summerfield and Hulton, 1994; Ludwig et al., 1996; Galy et al., 2015). However, our Godavari record shows that erosional output is maximized by aridity because significant rain and seasonal floods still occur during the summer monsoon season (Mujumdar et al., 1970; Kale, 2003). Aridification and/or agricultural expansion lead to changes in vegetation type (i.e., forest decrease in favor of savannah) and cover (i.e., shrinking of naturally vegetated lands in favor of agricultural and/or degrading arid lands) that exacerbate soil erosion (i.e., Langbein and Schum, 1958; Dunne, 1979; Walling and Webb, 1983; Istanbulluoglu and Bras, 2005; Vanacker et al., 2007; Collins and Bras, 2008).

\section{Carbon export from the Godavari Basin}

The terrigenous organic carbon exported by rivers consists of a mixture of dissolved and particulate components derived from contemporary vegetation and of carbon stored in bedrock, soils and fluvial sediments that may be signifi- cantly pre-aged (Smittenberg et al., 2006; Galy and Eglinton, 2011; Feng et al., 2013). On the Godavari slope, the terrigenous fraction dominates the total organic carbon (TOC) in marine sediments (Johnson et al., 2014). In agreement with this, TOC radiocarbon ages in our core have been previously found to be remarkably similar to co-located ages of the strictly terrigenous higher plant leaf-wax fraction (Ponton, 2012). This age similarity also excludes interferences from within-river biological productivity (e.g., Eglinton and Hamilton, 1967; Eglinton and Eglinton, 2008). To assess the variability of the terrigenous carbon age exported by Godavari River based on this understanding we used highresolution TOC radiocarbon measurements to calculate radiocarbon age offsets relative to the atmosphere (Soulet et al., 2016; see Supplement). Over the Holocene, these biospheric organic carbon radiocarbon age offsets in our core mirror the history of erosion in the basin (Fig. 2).

As a first-order observation, TOC ages (Fig. 2 and Supplement) are significantly older $\left(\sim 200\right.$ to $2000{ }^{14} \mathrm{C}$ years $)$ than their depositional age in our Godavari core. Before 5000 years ago the bulk organic carbon radiocarbon age offset was $\sim 600{ }^{14} \mathrm{C}$ years old on average. In contrast, the highly erosional regime under both climatic and early human pressure in the late Holocene led to the export of significantly older carbon from the terrestrial biosphere, i.e., $\sim 1300{ }^{14} \mathrm{C}$ on average. This increase in radiocarbon age offset occurred largely during the two aridification steps identified by Ponton et al. (2012): more abruptly between $\sim 5000$ and 4500 years ago and more gradually after $\sim 1700$ years ago (Fig. 2 ).

In the absence of significant storage in alluvial sediments in the Godavari catchment, several processes can explain the doubling in age offset over the Holocene: an overall slowing of soil carbon turnover in the drying climate of central India, a decrease in TOC contribution from contemporaneous vegetation relative to older (pre-aged) soil carbon input and/or deeper exhumation of soils contributing increasingly older carbon. Given the drastic changes in vegetation cover and increase in erosion in the Godavari Basin, a decrease in soil turnover is unlikely during the Holocene aridification process (Carvalhais et al., 2014). In turn, the good agreement between the pollen and leaf-wax $\delta^{13} \mathrm{C}$ records in our core (Ponton et al., 2012; Zorzi et al., 2015) with independent monsoon reconstructions suggests sustained delivery of recently fixed biospheric organic carbon to the delta. Thus, the doubling in age offset over the Holocene is best explained by increasing contributions from an older soil component, which could only come through deeper erosion. Because the age of soil organic carbon in soil profiles increases with depth (Trumbore, 2009), older mixtures imply a deeper soil erosion, whether uniform or through gullies, which are common especially on the Deccan Plateau (Kothyari, 1996). 


\section{The monsoon erosional pump}

Overall, these multiple lines of evidence indicate that soil erosion in the CMZ, as integrated by the Godavari River, increased throughout the basin immediately as climate began to dry at the end of the mid-Holocene and was further enhanced by Deccan agricultural activities in the late Holocene. The likely mechanism for this erosion acceleration is the extreme seasonal distribution of the rainfall that characterizes the monsoon (Wang and Ding, 2008), which promoted erosion on the more sparsely vegetated landscapes (Molnar, 2001; DiBiase and Whipple, 2011; Plink-Björklund, 2015). Our findings thus point to a veritable "monsoon erosional pump" that accelerates during minimum land cover conditions when the protective role of vegetation is reduced, whether naturally or by humans. The volume of total eroded sediments since the mid-Holocene must have been considerable as the continental margin growth accelerated with the shelf edge aggrading $\sim 80 \mathrm{~m}$ in the last $\sim 2000$ years alone (Forsberg et al., 2007).

This "land cover mode" of the monsoon erosional pump must have been active before the Holocene as well, affecting the transfer of terrigenous sediment, solutes and carbon from land to the ocean. The beat of monsoon precipitation on orbital timescales is not well constrained but considered to be modulated by at a combination of precession and obliquity frequencies based on monsoon wind reconstructions (e.g., Clemens and Prell, 2003). Such complex variability did not inevitably follow the sea level cyclicity (e.g., Goodbred and Kuehl, 2000), which is usually assumed to control most of the sediment transfer from land to the deep ocean (see Blum and Hattier-Womack, 2009, and references therein for an analysis underlining the increased recognition for a climate role). Thus, untangling the effects of the monsoon is difficult, especially during the Quaternary (e.g., Phillips et al., 2014), but may be easier to discern earlier when the sea level change magnitude was reduced. Land cover effects are less likely to occur in the upper basins of Himalayan monsoonal rivers where there are other sources of water such as snow or glaciers and where elevation (i.e., temperature) and orographic precipitation promote ecological stability (Galy et al., 2008a). The erosional pump in these high, steep regions is still active due to monsoonal seasonality but in a "topographic mode" dominated primarily by landslides (Montgomery and Brandon, 2002; but see Olen et al., 2016, for an alternative viewpoint). However, the land cover mode for the erosional pump should still be active in their lower basins where aridity controls vegetation type and cover (e.g., Galy et al., 2008b).

Recent coupled erosion-carbon cycling modeling suggests that long-term anthropogenic acceleration of erosion has had a significant impact on the global carbon cycle by intensifying the burial of terrigenous carbon (Wang et al., 2017). Prior to damming, the monsoon domain supplied $\sim 70 \%$ of the sediment load coming from large rivers (Syvitski and Saito,
2007), although it only covers $\sim 15 \%$ of the Earth's surface (Hsu et al., 2011). Therefore, we suspect that the cumulative effect of the monsoon erosional pump on the carbon budget was substantial in augmenting the burial of terrigenous carbon during the Holocene and needs to be estimated for inclusion in assessments of the net soil-atmosphere carbon exchange.

Data availability. The Supplement contains all data discussed in this paper, including radiocarbon and $\mathrm{Nd}$ isotope measurements.

\section{The Supplement related to this article is available online at https://doi.org/10.5194/esurf-5-781-2017-supplement.}

Competing interests. The authors declare that they have no conflict of interest.

Acknowledgements. We thank colleagues from the NGHP-01 expedition for intellectual interactions leading to this work. We also thank Daniel Montlucon for assistance in producing lab data. This study was supported by grants from Woods Hole Oceanographic Institution, the National Science Foundation (OCE-0841736 and OCE-0623766) and Swiss National Science Foundation ("CAPS LOCK” 200021-140850 and "CAPS-LOCK2” 200021-163162).

Edited by: Simon Mudd

Reviewed by: Piret Plink-Bjorklund and one anonymous referee

\section{References}

Allchin, F. R.: Early cities and states beyond the Ganges Valley, in: The Archaeology of Early Historic South Asia: The Emergence of Cities and States, edited by: Allchin, F. R., Cambridge University Press, Cambridge, UK, 123-151, 1995.

Allen, C. D. and Breshears, D. D.: Drought-induced shift of a forest-woodland ecotone: rapid landscape response to climate variation, P. Natl. Acad. Sci. USA, 95, 14839-14842, 1998.

Asouti, E. and Fuller, D. Q.: Trees and Woodlands in South India: Archaeological Perspectives, Left Coast Press, Walnut Creek, California, 2008.

Aufdenkampe, A. K., Mayorga, E., Raymond, P. A., Melack, J. M., Doney, S. C., and Alin, S. R.: Riverine coupling of biogeochemical cycles between land, oceans, and atmosphere, Front. Ecol. Environ., 9, 53-60, https://doi.org/10.1890/100014, 2011.

Battin, T. J., Luyssaert, S., Kaplan, L. A., Aufdenkampe, A. K., Richter, A., and Tranvik, L. J.: The boundless carbon cycle, Nat. Geosci., 2, 598-600, 2009.

Bayon, G., Dennielou, B., Etoubleau, J., Ponzevera, E., Toucanne, S., and Bermell, S.: Intensifying weathering and land use in Iron Age Central Africa, Science, 335, 1219-1222, 2012. 
Bejugam, P., Nayak G. N.: Source and depositional processes of the surface sediments and their implications on productivity in recent past off Mahanadi to Pennar River mouths, western Bay of Bengal, Palaeogeogr. Palaeocl., 483, 58-69, 2017.

Berkelhammer, M., Sinha, A., Stott, L., Cheng, H., Pausata, F. S. R., and Yoshimura, K.: An abrupt shift in the Indian monsoon 4000 years ago, in: Climates, Landscapes, and Civilizations, Geophysical Monograph, 198, edited by: Giosan, L., Fuller, D. Q., Nicoll, K., Flad, R. K., and Clift, P. D., American Geophysical Union, Washington D.C., 75-87, https://doi.org/10.1029/2012GM001207, 2012.

Bhattacharyya, T., Pal, D. K., Mandal, C., Chandran, P., Ray, S. K., Sarkar, D., Velmourougane, K., Srivastava, A., Sidhu, G. S., Singh, R. S., Sahoo, A. K., Dutta, D., Nair, K. M., Srivastava, R., Tiwary, P., Nagar, A. P., and Nimkhedkar, S. S.: Soils of India: historical perspective, classification and recent advances, Curr. Sci. India, 104, 1308-1323, 2003.

Bikshamaiah, G. and Subramanian, V.: Sediment transport of the Godavari River basin and its controlling factors, J. Hydrol., 101, 275-290, 1988.

Blum, M. D. and Hattier-Womack, J.: Climate change, sea-level change, and fluvial sediment supply to deepwater depositional systems, in: External Controls on Modern Clastic Turbidite Systems, SEPM Special Publication, 92, edited by: Kneller, B., Martinsen, O. J., and McCaffrey, B., Tulsa, Oklahoma, 15-39, 2009.

Bork, H. R. and Lang, A.: Quantification of past soil erosion and land use/land cover changes in Germany, in: Long Term Hillslope and Fluvial System Modelling, edited by: Lang, A., Hennrich, K. P., and Dikau, R., Springer, Berlin, Germany, 231-239, 2003.

Brubaker, R.: Aspects of mortuary variability in the South Indian Iron Age, Bull. Deccan College Res. Inst., 60, 253-302, 2000.

Carvalhais, N., Forkel, M., Khomik, M., Bellarby, J., Jung, M., Migliavacca, M., Mu, M., Saatchi, S., Santoro, M., Thurner, M., Weber, U., Ahrens, B., Beer, C., Cescatti, A., Randerson, J. T., and Reichstein, M.: Global covariation of carbon turnover times with climate in terrestrial ecosystems, Nature, 514, 213-217, 2014.

Chappell, A., Baldock, J., and Sanderman, J.: The global significance of omitting soil erosion from soil organic carbon cycling schemes, Nat. Clim. Change, 6, 187-191, 2016.

Clemens, S. C. and Prell, W. L.: A 350,000 year summer-monsoon multi-proxy stack from the Owen Ridge, Northern Arabian Sea, Mar. Geol., 201, 35-51, 2003.

Collett, T., Riedel, M., Cochran, J., Boswell, R., Presley, J., Kumar, P., Sathe, A., Sethi, A., Lall, M., and the NGHP Expedition Scientists: Indian National Gas Hydrate Program Expedition 01 report, U.S. Geological Survey Scientific Investigations Report 2012-5054, 1442 pp., 2015.

Collins, D. B. G. and Bras, R. L.: Climatic control of sediment yield in dry lands following climate and land cover change, Water Resour. Res., 44, W10405, https://doi.org/10.1029/2007WR006474, 2008.

Cui, M., Wang, Z., Rao, N. K., Sangode, S. J., Saito, Y., Chen, T., Kulkarni, Y. R., Kumar, K. C. V., and Demudu, G.: A mid-to-late Holocene record of vegetation decline and erosion triggered by monsoon weakening and human adaptations in the south-east Indian Peninsula, Holocene, https://doi.org/10.1177/0959683617715694, 2017.
DePaolo, D. J.: Neodymium Isotope Geochemistry, An Introduction, Springer-Verlag, Berlin, 187 pp., 1988.

Dhavalikar, M. K.: Towards an ecological model for chalcolithic cultures of central and western India, J. Anthropol. Archaeol., 3, 133-158, 1984.

DiBiase, R. A. and Whipple, K. X.: The influence of erosion thresholds and runoff variability on the relationships among topography, climate, and erosion rate, J. Geophys. Res.-Earth, 116, F04036, https://doi.org/10.1029/2011JF002095, 2011.

Dixit, Y., Hodell, D. A., and Petrie, C. A.: Abrupt weakening of the summer monsoon in northwest India similar to $4100 \mathrm{yr}$ ago, Geology, 42, 339-342, 2014.

Dotterweich, M.: The history of human-induced soil erosion: Geomorphic legacies, early descriptions and research, and the development of soil conservation - A global synopsis, Geomorphology, 201, 1-34, https://doi.org/10.1016/j.geomorph.2013.07.021, 2013.

Dunne, T.: Sediment yield and land use in tropical catchments, J. Hydrol., 42, 281-300, https://doi.org/10.1016/00221694(79)90052-0, 1979.

Edwards, W. M. and Owens, L. B.: Large storm effects on total soil erosion, J. Soil Water Conserv., 46, 75-78, 1991.

Eglinton, T. I. and Eglinton, G.: Molecular proxies for paleoclimatology, Earth Planet. Sc. Lett., 275, 1-16, 2008.

Eglinton, G. and Hamilton, R. J.: Leaf epicuticular waxes, Science, 156, 1322-1335, 1967.

Feng, X. J., Vonk, J. E., van Dongen, B. E., Gustafsson, O., Semiletov, I. P., Dudarev, O. V., Wang, Z. H., Montlucon, D. B., Wacker, L., and Eglinton, T. I.: Differential mobilization of terrestrial carbon pools in Eurasian Arctic river basins, P. Natl. Acad. Sci. USA, 110, 14168-14173, 2013.

Fleitmann, D., Burns, S. J., Mudelsee, M., Neff, U., Kramers, J., Mangini, A., and Matter, A.: Holocene forcing of the Indian monsoon recorded in a stalagmite from Southern Oman, Science, 300, 1737-1739, 2003.

Forsberg, C. F., Solheim, A., Kvalstad, T. J., Vaidya, R., and Mohanty, S.: Slope instability and mass transport deposits on the Godavari river delta, east Indian margin from a regional geological perspective, Submarine Mass Movements and Their Consequences, 27, 19-27, 2007.

Fuller, D. Q.: Asia, South: Neolithic cultures, in: Encyclopedia of Archaeology, edited by: Pearsall, D., Elsevier Academic Press, San Diego, California, 756-768, 2008.

Fuller, D. Q.: Finding plant domestication in the Indian subcontinent, Curr. Anthropol., 52, S347-S362, 2011.

Fuller, D. Q. and Madella, M.: Issues in Harappan Archaeobotany: Retrospect and Prospect, in: Indian Archaeology in Retrospect, Volume II. Protohistory, edited by: Settar, S. and Korisettar, R., Indian Council for Historical Research, New Delhi, 47-80, 2001.

Galy, V. and Eglinton, T. I.: Protracted storage of biospheric carbon in the Ganges-Brahmaputra basin, Nat. Geosci., 4, 843-847, 2011.

Galy, V., François, L., France-Lanord, C., Faure, P., Kudrass, H., Palhol, F., and Singh, S. K.: $\mathrm{C}_{4}$ plants decline in the Himalayan basin since the Last Glacial Maximum, Quaternary Sci. Rev., 27, 1396-1409, 2008a.

Galy, V., France-Lanord, C., and Lartiges, B.: Loading and fate of particulate organic carbon from the Himalaya to the Ganga- 
Brahmaputra delta, Geochim. Cosmochim. Ac., 72, 1767-1787, 2008b.

Galy, V., Peucker-Ehrenbrink, B., and Eglinton, T.: Global carbon export from the terrestrial biosphere controlled by erosion, Nature, 521, 204-207, 2015.

Goodbred, S. L. and Kuehl, S. A.: Enormous Ganges-Brahmaputra sediment discharge during strengthened early Holocene monsoon, Geology, 28, 1083-1086, 2000.

Gunnell, Y., Anupama, K., and Sultan, B.: Response of the South Indian runoff harvesting civilization to northeast monsoon rainfall variability during the last 2000 years: instrumental records and indirect evidence, Holocene, 17, 207-215, 2007.

Gupta, A. K., Anderson, D. M., and Overpeck, J. T.: Abrupt changes in the Asian southwest monsoon during the Holocene and their links to the North Atlantic Ocean, Nature, 421, 354-357, 2003.

Hilton, R. G., Galy, A., Hovius, N., Chen, M. C., Horng, M. J., and Chen, H.: Tropical-cyclone-driven erosion of the terrestrial biosphere from mountains, Nat. Geosci., 1, 759-762, 2008.

Hoffmann, T., Mudd, S. M., van Oost, K., Verstraeten, G., Erkens, G., Lang, A., Middelkoop, H., Boyle, J., Kaplan, J. O., Willenbring, J., and Aalto, R.: Short Communication: Humans and the missing C-sink: erosion and burial of soil carbon through time, Earth Surf. Dynam., 1, 45-52, https://doi.org/10.5194/esurf-145-2013, 2013.

Hsu, P. C., Li, T., and Wang, B.: Trends in global monsoon area and precipitation over the past 30 years, Geophys. Res. Lett., 38, L08701, https://doi.org/10.1029/2011GL046893, 2011.

Istanbulluoglu, E. and Bras, R. L.: Vegetation-modulated landscape evolution: Effects of vegetation on landscape processes, drainage density, and topography, J. Geophys. Res.-Earth, 110, F02012, https://doi.org/10.1029/2004jf000249, 2005.

Johnson, J. E., Phillips, S. C., Torres, M. E., Piñero, E., Rose, K. K., and Giosan, L.: Influence of total organic carbon deposition on the inventory of gas hydrate in the Indian continental margins, Mar. Petrol. Geol., 58, 406-424, 2014.

Joshi, R. K., Mazumdar, A., Peketi, A., Ramamurty, P. B., Naik, B. G., Kocherla, M., Carvalho, M. A., Mahalakshmi, P., Dewangan, P., and Ramana, M. V.: Gas hydrate destabilization and methane release events in the Krishna-Godavari Basin, Bay of Bengal, Mar. Petrol. Geol., 58, 476-489, 2014.

Kajale, M. D.: Plant Economy, in: Excavations at Inamgaon, Vol. 1, Part 2, edited by: Dhavalikar, M. K., Sankalia, H. D., and Ansari, Z. D., Deccan College Postgraduate and Research Institute, Pune, 727-821, 1988

Kale, V. S.: Fluvial geomorphology of Indian rivers: an overview, Prog. Phys. Geog., 26, 400-433, 2002.

Kale, V. S.: Geomorphic Effects of Monsoon Floods on Indian Rivers, Natural Hazards, 28, Springer, New York, 2003.

Kaplan, J. O., Krumhardt, K. M., Ellis, E. C., Ruddiman, W. F., Lemmen, C., and Klein Goldewijk, K.: Holocene carbon emissions as a result of anthropogenic land cover change, Holocene, 21, 775-791, https://doi.org/10.1177/0959683610386983, 2010.

Kothyari, U. C.: Erosion and Sedimentation Problems in India, in: Erosion and Sediment Yield: Global and Regional Perspectives (Proceedings of the Exeter Symposium, July 1996), 1AHS Publ. 236, edited by: Walling, D. E. and Webb, B. W., IAHS Press, Wallingford, Oxfordshire, UK, 531-540, 1996.
Kulkarni, Y. R., Sangode, S. J., Meshram, D. C., Patil, S. K., and Dutt, Y.: Mineral magnetic characterization of the Godavari River sediments, J. Geol. Soc. India, 81, 376-384, 2014.

Kulkarni, Y. R., Sangode, S. J., Bloemandal, J., Meshram, D. C., and Suresh, N.: Mineral magnetic characterization of the Godavari River and western Bay of Bengal sediments: Implications to source to sink relations, J. Geol. Soc. India, 85, 71-78, 2015.

Lal, R.: Soil carbon sequestration impacts on global climate change and food security, Science, 304, 1623-1627, 2004.

Lambeck, K., Rouby, H., Purcell, A., Sun, Y., and Sambradge, M.: Sea level and global ice volumes from the Last Glacial Maximum to the Holocene, P. Natl. Acad. Sci. USA, 111, 15296-15303, 2014.

Langbein, W. B. and Schumm, S. A.: Yield of sediment in relation to mean annual precipitation, EOS T. Am. Geophys. Un., 39, 10761084, 1958.

Ludwig, W., Probst, J. L., and Kempe, S.: Predicting the oceanic input of organic carbon by continental erosion, Global Biogeochem. Cy., 10, 23-41, 1996.

Mazumdar, A., Dewangan, P., Joao, H. M., Peketi, A., Khosla, V. R., Kocherla, M., Badesab, F. K., Joshi, R. K., Roxanne, P., Ramamurty, P. B., Karisiddaiah, S. M., Patil, D. J., Dayal, A. M., Ramprasad, T., Hawkesworth, C. J., and Avanzinelli, R.: Evidence of paleo-cold seep activity from the Bay of Bengal, offshore India, Geochem. Geophy. Geosy., 10, Q06005, https://doi.org/10.1029/2008GC002337, 2009.

McLennan, S. M. and Hemming, S.: Samarium/neodymium elemental and isotopic systematics in sedimentary rocks, Geochim. Cosmochim. Ac., 56, 887-898, 1992.

Mohanty, R. K. and Selvakumar, V.: The archaeology of the Megaliths in India: 1947-1997, in: Indian Archaeology in Retrospect, 1. Prehistory, edited by: Settar, S. and Korisettar, R., Manohar, New Delhi, 313-352, 2001.

Molnar, P.: Climate change, flooding in arid environments, and erosion rates, Geology, 29, 1071-1074, 2001.

Montgomery, D. R.: Soil erosion and agricultural sustainability, P. Natl. Acad. Sci. USA, 104, 13268-13272, 2007.

Montgomery, D. R. and Brandon, M. T.: Topographic controls on erosion rates in tectonically active mountain ranges, Earth Planet. Sc. Lett., 201, 481-489, 2002.

Mujumdar, G. G., Rajaguru, S. N., and Papu, R. S.: The recent Godavari Flood (September 1969) and its relevance to prehistoric archeology, Bull. Deccan College Res. Inst., 24, 1-17, 1970.

NBSS \& LUP (National Bureau of Soil Survey \& Land Use Planning of India): Soils of India, (Suborder Associations), Map scale $1:$ 6,300,000, NBSS \& LUP, Nagpur, 1983.

Olen, S. M., Bookhagen, B., and Strecker, M. R.: Role of climate and vegetation density in modulating denudation rates in the Himalaya, Earth Planet. Sc. Lett., 445, 57-67, 2016.

Parabrahma Sastry, P. V.: The Early Historic Transition, in: Pre- and Protohistoric Andhra Pradesh up to 500 BC, edited by: Murty, M. L. K., Orient Longman, New Delhi, 139-147, 2003.

Phillips, S. C., Johnson, J. E., Giosan, L., and Rose, K.: Monsooninfluenced variation in productivity and lithogenic sediment flux since $110 \mathrm{ka}$ in the offshore Mahanadi Basin, northern Bay of Bengal, Mar. Petrol. Geol., 58, 502-525, 2014.

Plink-Björklund, P.: Morphodynamics of rivers strongly affected by monsoon precipitation: Review of depositional style and forcing factors, Sediment. Geol., 323, 110-147, 2015. 
Ponton, C.: Aridification of the Indian subcontinent during the Holocene: implications for landscape evolution, sedimentation, carbon cycle, and human civilizations, Doctoral dissertation, Massachusetts Institute of Technology, Cambridge, MA, USA, https://doi.org/10.1575/1912/5291, 2012.

Ponton, C., Giosan, L., Eglinton, T. E., Fuller D. Q., Johnson, J. E., Kumar, P., and Collett, T. S.: Holocene Aridification of India, Geophys. Res. Lett., 39, L03704, https://doi.org/10.1029/2011GL050722, 2012.

Prasad, S. and Enzel, Y.: Holocene paleoclimates of India, Quaternary Res., 66, 442-453, 2006.

Prasad, S., Anoop, A., Riedel, N., Sarkar, S., Menzel, P., Basavaiah, N., Krishnan, R., Fuller, D., Plessen, B., Gaye, B., and Röhl, U.: Prolonged monsoon droughts and links to Indo-Pacific warm pool: A Holocene record from Lonar Lake, central India, Earth Planet. Sc. Lett., 391, 171-182, 2014.

Ramprasad, T., Dewangan, P., Ramana, M. V., Mazumdar, A., Karisiddaiah, S. M., Ramya, E. R., and Sriram, G.: Evidence of slumping/sliding in Krishna-Godavari offshore basin due to gas/fluid movements, Mar. Petrol. Geol., 28, 1806-1816, 2011.

Rao, K. N., Sadakata, N., Malini, B. H., and Takayasu, K.: Sedimentation processes and asymmetric development of the Godavari delta, India, in: River Deltas, Concepts, Models and Examples, SEPM Special Publication, 83, edited by: Giosan, L. and Bhattacharya, J. P., Tulsa, Oklahoma, 433-449, 2005.

Regnier, P., Friedlingstein, P., Ciais, P., Mackenzie, F. T., Gruber, N., Janssens, I. A., Laruelle, G. G., Lauerwald, R., Luyssaert, S., Andersson, A. J., Arndt, S., Arnosti, C., Borges, A. V., Dale, A. W., Gallego-Sala, A., Goddéris, Y., Goossens, N., Hartmann, J., Heinze, C., Ilyina, T., Joos, F., LaRowe, D. E., Leifeld, J., Meysman, F. J. R., Munhoven, G., Raymond, P. A., Spahni, R., Suntharalingam, P., and Thullner, M.: Anthropogenic perturbation of the carbon fluxes from land to ocean, Nat. Geosci., 6, 597-607, 2013

Reichstein M., Bahn, M., Ciais, P., Frank, D., Mahecha, M. D., Seneviratne, S. I., Zscheischler, J., Beer, C., Buchmann, N., Frank, D. C., Papale, D., Rammig, A., Smith, P., Thonicke, K., van der Velde, M., Vicca, S., Walz, A., and Wattenbach, M.: Climate extremes and the carbon cycle, Nature, 500, 287-295, 2013.

Roberts, P., Boivin, N., Petraglia, M., Masser, P., Meece, S., Weisskopf, A., and Fuller, D. Q.: Local diversity in settlement, demography and subsistence across the southern Indian Neolithic-Iron Age transition: site growth and abandonment at Sanganakallu-Kupgal, Archaeol. Anthrop. Sci., 8, 575-599, 2016.

Sangode, S. J., Suresh, N., and Bagati, T. N.: Godavari source in the Bengal fan sediments: results from magnetic susceptibility dispersal pattern, Curr. Sci. India, 80, 660-664, 2001.

Sarkar, S., Prasad, S., Wilkes, H., Riedel, N., Stebich, M., Basavaiah, N., and Sachse, D.: Monsoon source shifts during the drying mid-Holocene: Biomarker isotope based evidence from the core "monsoon zone" (CMZ) of India, Quaternary Sci. Rev., 123, 144-157, 2015

Singh, G., Babu, R., Narain, P., Bhushan, L. S., and Abrol, A. P.: Soil erosion rates in India, J. Soil Water Conserv., 47, 97-99, 1992.

Sinha, A., Stott, L., Berkelhammer, M., Cheng, H., Edwards, R. L., Buckley, B., Aldenderfer, M., and Mudelsee, M.: A global con- text for megadroughts in monsoon Asia during the past millennium, Quaternary Sci. Rev., 30, 47-62, 2011.

Soulet, G., Skinner, L. C., Beaupré, S. R., and Galy, V.: A note on reporting of reservoir ${ }^{14} \mathrm{C}$ disequilibria and age offsets, Radiocarbon, 58, 205-211, 2016.

Smittenberg, R. H., Eglinton, T. I., Schouten, and Damste, J. S. S.: Ongoing buildup of refractory organic carbon in boreal soils during the Holocene, Science, 314, 1283-1286, 2006.

Sridhar, P. N., Ali, M. M., Vethamony, P., Babu, M. T., Ramana, I. V., and Jayakumar, S.: Seasonal Occurrence of Unique Sediment Plume in the Bay of Bengal, EOS T. Am. Geophys. Union, 89, 22-23, 2008

Stallard, R. F.: Terrestrial sedimentation and the carbon cycle: Coupling weathering and erosion to carbon burial, Global Biogeochem. Cy., 12, 231-257, 1998.

Summerfield, M. A. and Hulton, N. J.: Natural controls of fluvial denudation rates in major world drainage basins, J. Geophys. Res. 99, 13871-13883, https://doi.org/10.1029/94JB00715, 1994.

Syvitski, J. P. M. and Saito, Y.: Morphodynamics of deltas under the influence of humans, Global Planet. Change, 57, 261-282, 2007.

Trumbore, S.: Radiocarbon and Soil Carbon Dynamics, Annu. Rev. Earth Pl. Sc., 37, 47-66, 2009.

Vanacker, V., von Blanckenburg, F., Govers, G., Molina, A., Poesen, J., Deckers, J., and Kubik, P.: Restoring dense vegetation can slow mountain erosion to near natural benchmark levels, Geology, 35, 303-306, https://doi.org/10.1130/G23109A.1, 2007.

van Andel, T. H., Zangger, E., and Demitrack, A.: Land use and soil erosion in prehistoric and historical Greece, J. Field Archaeol., 17, 379-396, https://doi.org/10.2307/530002, 1990.

van Oost, K., Verstraeten, G., Doetterl, S., Notebaert, B., Wiaux, F., Broothaerts, N., and Six, J.: Legacy of human-induced C erosion and burial on soil-atmosphere C exchange, P. Natl. Acad. Sci. USA, 109, 19492-19497, 2012.

Vanwalleghem, T., Gómez, J. A., Infante Amate, J., González de Molina, M., Vanderlinden, K., Guzmán, G., Laguna, A., and Giráldez, J. V.: Impact of historical land use and soil management change on soil erosion and agricultural sustainability during the Anthropocene, Anthropocene, 17, 13-29, 2017.

Walling, D. E. and Webb, B. W.: Patterns of sediment yields, in: Background to Paleohydrology, edited by: Gregory, K. J., John Wiley \& Sons, London, 69-100, 1983.

Wang, B. and Ding, Q.: Global monsoon: Dominant mode of annual variation in the tropics, Dynam. Atmos. Oceans, 44, 165-183, 2008.

Wang, Z., Hoffmann, T., Six, J., Kaplan, J. O., Govers, G., Doetterl, S., and van Oost, K.: Human-induced erosion has offset one-third of carbon emissions from land cover change, Nat. Clim. Change, 7, 345-349, 2017.

Wilkinson, B. H. and McElroy, B. J.: The impacts of humans on continental erosion and sedimentation, Geol. Soc. Am. Bull., 119, 140-156, 2007.

Zorzi, C., Goñi, M. F. S., Anupama, K., Prasad, S., Hanquiez, V., Johnson, J., and Giosan, L.: Indian monsoon variations during three contrasting climatic periods: The Holocene, Heinrich Stadial 2 and the last interglacial-glacial transition, Quaternary Sci. Rev., 125, 50-60, 2015. 